\title{
THE ENGINEERING APPLICATIONS OF A HF-FREE DIRECTIONALLY SOLIDIFIED SUPERALLOY IN THE AVIATION INDUSTRY OF CHINA
}

\author{
Sun Chuanqi, Li Qijiuan, Wu Changxin, and Tian Shifan \\ Beijing Institute of Aeronutical Materials, Beijing 100095, PRC \\ John F Radavich \\ Purdue University, West Lafayette, 47907 IN, USA
}

\begin{abstract}
Most directionally solidified (DS) superalloy blades and vanes operating at or above $950^{\circ} \mathrm{C}$ in jet engines usually contain Hafnium (Hf) to improve mechanical properties and performances. The addition of $\mathrm{Hf}$ increases the cost of these alloys and may cause a number of problems which limit their usage. At BIAM, a Hf-free DS superalloy, DZ4, was developed in the late 1970's. The improved mechanical properties, and good castability of this alloy, combined with low cost, make the DZ4 alloy suitable for production applications. In this paper, compositional and microstructural characterizations will be discussed. Mechanical properties, and engineering applications for the alloy will be presented.
\end{abstract}

Introduction

In the early 1960's when the first American DS superalloy, PWA 664, was developed using the Mar M200 composition, alloy properties were greatly improved through the use of directional solidification. Unfortunately, during the production of DS hollow blades, hot tearing problems appeared. In the early 70's, an alloy, PWA 1422 (Mar M200 +2\% Hf) was invented by Duhl et al [1], which solved the hot tearing problem. The effect of the Hf addition is to change the morphology of the large script-like primary MC carbide into fine dispersed IIf-rich MC2 carbides [2]. The addition of Hf also resulted in a great increase in the amount of $\gamma / \gamma^{\prime}$ eutectic phase. For example, in alloys containing 1.5- $2.4 \mathrm{wt} \% \mathrm{Hf}$, the amount of $\gamma / \gamma^{\prime}$ eutectic may increase from $\sim 6 \%$ to $20 \%$ on average. As the $\gamma / \gamma^{\prime}$ eutectic is mainly located at the longitudinal grain boundaries and interdendritic regions, it toughens the grain boundaries. Production experience has proven that the Hf-addition is effective in eliminating cracking in directionally solidified blades, especially DS hollow blades. Currently, most alloys used for DS blades, contain Hf (see Table I) for improving castability. However, there are shortcomings brought about by the addition of $\mathrm{Hf}$, namely; 1) cost of Hf containing alloy is much higher than Hifree alloys. and the recycling of Hf containing alloy revert remains difficult; 2) the incipient melting temperature of Hf containing alloys is significantly lowered due to the presence of low melting phases such as $\mathrm{Ni}_{5} \mathrm{Hf}$, which in turn effect high temperature properties, especially properties above $1000^{\circ} \mathrm{C}$. In order to overcome the shortcomings of Hf-containing DS superalloys, research and development work was started in the late 70's at BIAM. The target goals were as follows: 1) Alloy properties must be essentially maintained at levels equivalent to that of alloy PWA 1422 ; 2) The alloy should not contain Hf, but retain good castability; 3 ) Consideration must be given to low specific weight and low cost. In the early 80 's, a Hf-free DS superalloy DZ4 was developed at BIAM in China which met the target property and cost goals. The alloy composition, phase data and physical parameters are presented in Table II. The alloy has entered production, and since the late 80 's the engineering applications for the DZ4 alloy have been increasing.

Table I Composition of Typical DS Superalloys Widely Used in Jet Engines

\begin{tabular}{|c|c|c|c|c|c|c|c|c|c|c|c|c|c|c|c|c|}
\hline \multirow[t]{2}{*}{ Alloy } & \multicolumn{14}{|c|}{ Composition wt. \% } & \multirow{2}{*}{$\begin{array}{l}\text { Density } \\
\mathrm{g} / \mathrm{cm}^{3}\end{array}$} & \multirow{2}{*}{$\begin{array}{c}\text { Relative } \\
\text { Cost }\end{array}$} \\
\hline & $\mathrm{C}$ & $\mathrm{Cr}$ & $\mathrm{Co}$ & $\mathrm{W}$ & Mo & $\mathrm{Nb}$ & $\mathrm{Ta}$ & $\operatorname{Re}$ & $\mathrm{Al}$ & $\mathrm{Ti}$ & Hf & $B$ & $\mathrm{Zr}$ & $\mathrm{Ni}$ & & \\
\hline $\mathrm{DZ4}$ & 0.13 & 9.5 & 6 & 5.5 & 3.8 & & & & 6.2 & 1.9 & & 0.015 & & Bal. & 8.15 & $1 \mathrm{X}$ \\
\hline PWA 1422 & 0.14 & 9.0 & 10 & 12 & & 1 & & & 5 & 2.0 & 1.5 & 0.015 & $<0.1$ & Bal. & 8.5 & $2 X$ \\
\hline DS Rene' 150 & 0.06 & 5 & 5 & 1 & 1 & & 6 & 3 & 5.5 & & 1.5 & 0.015 & & Bal. & 8.5 & $12 X$ \\
\hline DS MM002 & 0.14 & 9 & 10 & 10 & $<0.5$ & & 2.5 & & 5.5 & 1.5 & 1.5 & 0.015 & 0.05 & Bal. & 8.5 & $2.5 \mathrm{X}$ \\
\hline DS Rene' 80 & 0.12 & 14 & 9.5 & 4 & 4 & & & & 3 & 4.0 & 1.5 & 0.015 & $<0.1$ & Bal. & 8.2 & $2 X$ \\
\hline
\end{tabular}


Table II Chemical Composition, Phase Data and Physical Parameters of Alloy DZ4

\begin{tabular}{|l|l|l|l|l|l|l|l|l|l|}
\hline $\mathrm{C}$ & $\mathrm{Cr}$ & $\mathrm{Co}$ & $\mathrm{W}$ & $\mathrm{Mo}$ & $\mathrm{Al}$ & $\mathrm{Ti}$ & $\mathrm{Al}+\mathrm{Ti}$ & $\mathrm{B}$ & $\mathrm{Ni}$ \\
\hline $0.1 / 0.16$ & $9.0 / 10.0$ & $5.5 / 6.0$ & $5.1 / 5.8$ & $3.5 / 4.2$ & $5.6 / 6.4$ & $1.6 / 2.2$ & $>7.6$ & $0.012 / 0.025$ & Bal. \\
\hline
\end{tabular}

\begin{tabular}{|c|c|c|c|c|c|c|c|}
\hline$\gamma^{\prime}$ total \% & & $\mathrm{a} \gamma$ & $\mathrm{a} \gamma^{\prime}$ & $\left(\mathrm{a} \gamma^{-\mathrm{a}} \gamma^{\prime}\right) / \mathrm{a} \gamma$ & $\mathrm{N}_{\mathrm{v}}$ & Density & $\mathrm{T}_{\mathrm{m}}{ }^{\circ} \mathrm{C}$ \\
\hline wt. & at. & $(\AA)$ & $(\AA)$ & $\%$ & & $\mathrm{gm} / \mathrm{cm}^{3}$ & incipient \\
\hline 60.78 & 62.82 & 3.588 & 3.578 & 0.27 & 2.16 & 8.19 & 1290 \\
\hline
\end{tabular}

* calculated according to a nominal composition

Table III Chemical Composition of Alloy DZ3 and the Experimental Alloy DZ4

\begin{tabular}{|c|c|c|c|c|c|c|c|c|c|c|c|}
\hline & \multicolumn{10}{|c|}{ Composition wt \% } \\
\cline { 2 - 14 } & $\mathrm{C}$ & $\mathrm{Cr}$ & $\mathrm{Co}$ & $\mathrm{W}$ & $\mathrm{Mo}$ & $\mathrm{Al}$ & $\mathrm{Ti}$ & $\mathrm{Zr}$ & $\mathrm{Ce}$ & $\mathrm{B}$ & $\mathrm{Ni}$ \\
\hline DZ3 & .14 & 10.4 & 5 & 5.3 & 4.1 & 5.6 & 2.6 & 0.1 & 0.01 & 0.01 & Bal. \\
\hline DZ4 & .14 & 9.5 & 6 & 5.4 & 3.8 & 6.2 & 1.8 & - & - & 0.015 & Bal. \\
\hline
\end{tabular}

\section{Alloy Design}

The alloy composition is designed to eliminate the $\gamma / \gamma^{\prime}$ eutectic, maintain a high $\gamma^{\prime}$ volume fraction, and achieve good castability. The solution temperature must be as high as possible so that the alloy can meet the requirements for high mechanical properties, and structural stability for long term service. At the same time the alloy should have a low density and not contain rare expensive elements. By optimizing the $\gamma^{\prime}$ forming element content ( $\mathrm{T} i, \mathrm{Al}$ and $\mathrm{Zr}$ ), an alloy (DZ3) with 3-5 wt. \% $\gamma / \gamma^{\prime}$ eutectic (see Table III) was developed [3]. DTA and isothermal quench experiments have been done for alloys DZ3 and DZ4[4]. The results of isothermal solidification tests show that at $1370^{\circ} \mathrm{C}$, alloy DZ4 is essentially liquid except for a few primary crystals which appear at the periphery adjacent to the mold (shell). At $1360^{\circ} \mathrm{C}$, about $6.8 \%$ of the melt has solidified as $\gamma$ primary crystals and precipitated, while at $1350^{\circ} \mathrm{C} \sim 70.8 \%$ of the total volume has solidified. After isothermal solidificationat at $1330^{\circ} \mathrm{C}$ for $15 \mathrm{~min}$. approximately $12.3 \%$ of the melt is liquid and $\mathrm{MC}$ carbides begin to precipitate out. At $1280^{\circ} \mathrm{C}$ only $0.65 \%$ of the liquid phase remains, which contains mainly $\mathrm{M}_{3} \mathrm{~B}_{2}$ and carbides [5]. Thermal solidification tests show the results of the absence of the $\gamma / \gamma^{\prime}$ eutectic phase at $1370^{\circ} \mathrm{C}$. The DZ4 alloy remains essentially solid below $1270^{\circ} \mathrm{C}$. There is no secondary $\gamma^{\prime}$ precipitation in the alloy until isothermal solidification at $1180^{\circ} \mathrm{C}$. After 15 minutes at $1150^{\circ} \mathrm{C}$, secondary $\gamma^{\prime}$ appears at the interdendritic regions, but at the dendritic stems there is no sign of secondary $\gamma^{\prime}$ phase. The liquidus $\left(T_{L}\right)$ and solidus $\left(\mathrm{T}_{\mathrm{S}}\right)$ for alloys DZ3 and DZ4 are presented in Table IV

Table IV Liquidus and Solidus of DZ3 and DZ4

\begin{tabular}{|c|c|c|c|c|c|c|}
\hline \multirow{3}{*}{ Alloy } & \multicolumn{3}{|c|}{ Heating } & \multicolumn{3}{c|}{ Cooling } \\
\cline { 2 - 7 } & $\mathrm{T}_{\mathrm{L}}$ & $\mathrm{T}_{\mathrm{S}}$ & $\mathrm{T}_{\mathrm{L}}-\mathrm{T}_{\mathrm{S}}$ & $\mathrm{T}_{\mathrm{L}}$ & $\mathrm{T}_{\mathrm{L}}$ & $\mathrm{T}_{\mathrm{L}}-\mathrm{T}_{\mathrm{S}}$ \\
\hline $\mathrm{DZ} 4$ & 1365 & 1280 & 85 & 1356 & 1296 & 60 \\
\hline $\mathrm{DZ3}$ & 1345 & 1180 & 165 & 1347 & 1206 & 141 \\
\hline
\end{tabular}

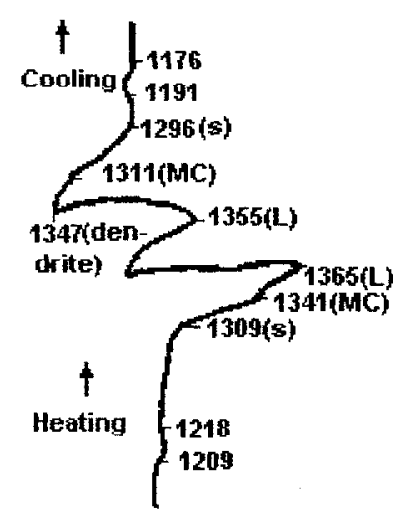

(a)

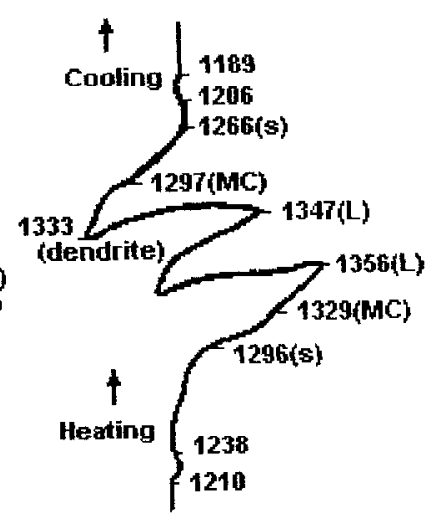

(b)
Figure 1. DTA Curves for Alloy DZ4 (a) and Alloy DZ3 (b)

\section{Castability}

Comparing DZ3 with DZ4, (Table IV) shows [5] that Zr has been removed from alloy DZ4 and the Ti found in DZ3 has been partially replaced by the equivalent amount of Al. There are also minor adjustments in Mo and W. It is believed that lowering the amount of elements, such as $\mathrm{Ti}$ and $\mathrm{Zr}$, which concentrate in the $\gamma / \gamma^{\prime}$ eutectic, will reduce the amount of this phase while maintaining a high volume fraction of $\gamma^{\prime}$. Experimental results indicate that no $\gamma / \gamma^{\prime}$ eutectic phase appears in the DZ4 alloy in the as cast condition, no matter how fast or slow it is cooled, or even when the $\mathrm{Al}+\mathrm{Ti}$ content is at the upper limits of the specification. The elimination of the $\gamma / \gamma^{\prime}$ eutectic further narrows the temperature differential between the Liquidus $\left(\mathrm{T}_{\mathrm{L}}\right)$ and Solidus $\left(\mathrm{T}_{\mathrm{S}}\right)$ in the alloy. This is regarded as the main reason castability is improved for the Hf-free superalloy. It is clear from Table IV, that the temperature differential between $T_{L}$ and $T_{S}$ for $D Z 4$ is approximately half that of DZ3 alloy. In practice the differences in $\triangle \mathrm{T}$ between two alloys is reflected in their relative castability. The DZ3 alloy with a large $\Delta T$, is prone to hot tearing, and a relatively high incidence of cracking has been observed during the casting of 
DS hollow blades. Hollow blades cast from DZ4 alloy, with a small $\triangle T$, do not experience hot tearing problems.

\section{Microstructure}

The phase constituents in the as cast condition are as follows: $\gamma$ matrix, intermetallic $\gamma^{\prime}, \mathrm{MC}$ carbides and a minor anount of $\mathrm{M}_{3} \mathrm{~B}_{2}$. In the heat treated or service condition, $\gamma^{\prime}$ transforms into fine cubes $(0.3-0.5 \mu \mathrm{m})$ dispersed uniformly distributed throughout the matrix, and $\mathrm{M}_{6} \mathrm{C}$ and $\mathrm{M}_{22} \mathrm{C}_{6}$ carbides may also precipitate. The absence of $\gamma / \gamma^{\prime}$ eutectic in DZ4 is one of the unique microstructural features of this alloy which contains a high volume fraction of $\gamma^{1}$ ( see Figure 1).

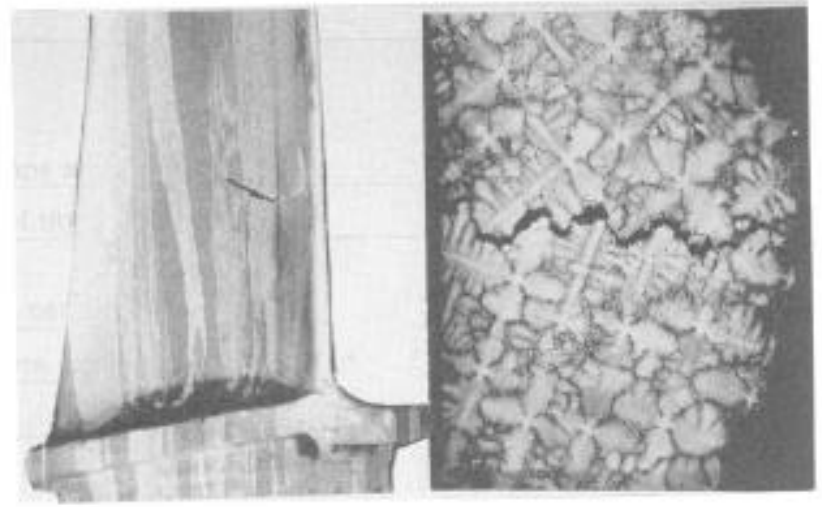

Figure 2. Cracking in DS Hollow Blades Cast From DZ3 Alloy.

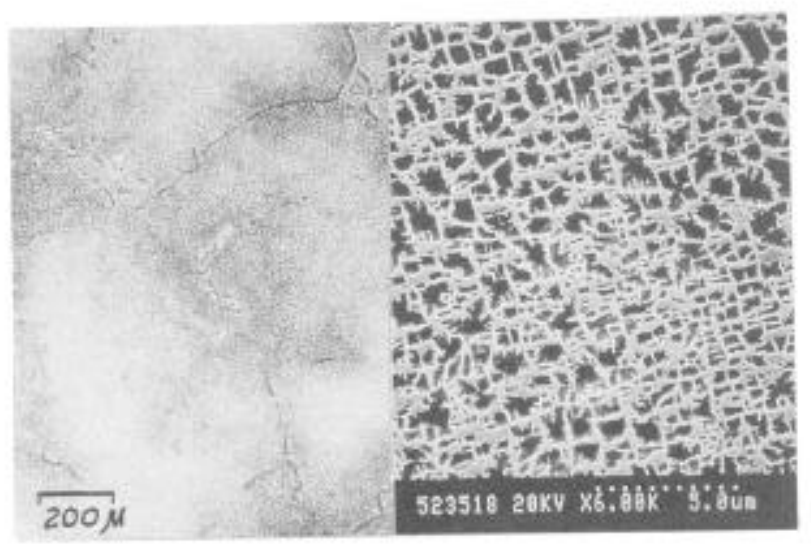

Figure 3. Microstructure of DZ4 Alloy As Cast (Left) After Heat Treatment (Right)

Mechanical Properties

As shown in Figures 4 and 5, alloy tensile strength and stress ruprure life increase at high and intermediate temperatures as the solution temperature increases, Solutioning DZ4 at $1270^{\circ} \mathrm{C}$ does not lower alloy properties. In some alloys with $\mathrm{Hf}$, solutioning at $1250^{\circ} \mathrm{C}$. significantly reduces alloy properties, because incipient melted regions are produced in the microstructure. Therefore, the elimination of the $\gamma / \gamma^{\prime}$ eutectic enables solution heat treatment to be performed at high temperatures without producing incipient melting, and optimizing mechanical properties.

The DZ4 alloy property data accurnulated during engineering development, are presented in Tables V and VI. Data listed in Table $V$ and Figure 6 show that the rupture properties of DZA are superior to orher DS superalloys, such as PWA 1422, Rene' 125 and DS MM002. for the entire spectrum of service temperatures. The superiority of alloy DZ4 becames more apparent at temperatures above $1000^{\circ} \mathrm{C}$. Work done by Wakusick [6] showed that castability is related to the $\gamma^{\prime}$ volume fraction of the alloy, and as the $\gamma^{\prime}$ volume fraction increases, the castability is degraded. Often achicving high temperature properties and good castability are conflicting goals. In past alloy development programs, in order to improve alloy castability without $\mathrm{Hf}$, high temperature properties had to be sacrificed. In alloy DZ4, however, $\gamma^{\prime}$ volume fraction is as high $(62 \mathrm{vol} \%)$, or higher then that of other typical DS superalloys, while excellent castability is maintained, due to the elimination of the $\gamma / \gamma$ ' eutectic through compositional design.

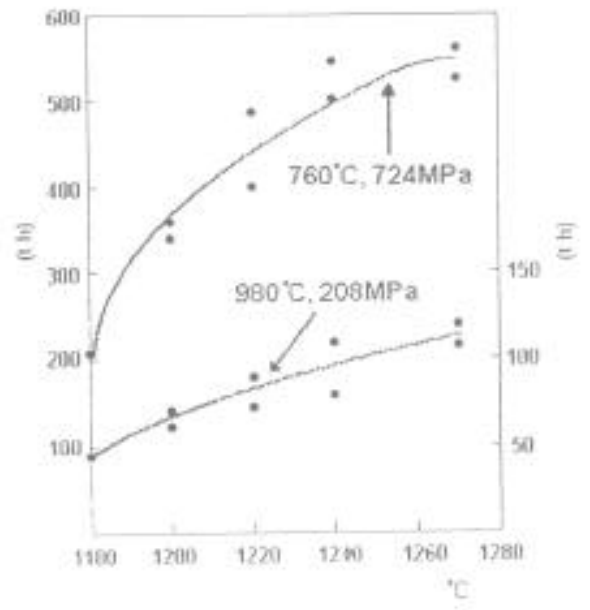

Figure 4. Effect of Solution Temperature on the Stress-Rupture Properties of DZ4 at 760 and $980^{\circ} \mathrm{C}$
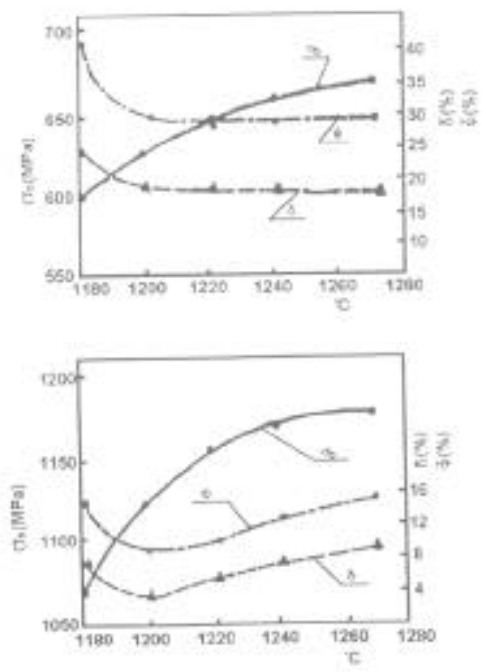

Figure 5. Effect of Solution Temperature on the Tensile Properties at $760^{\circ} \mathrm{C}(\mathrm{a})$, and $980^{\circ} \mathrm{C}$ (b) 
Stress-Rupture Properties

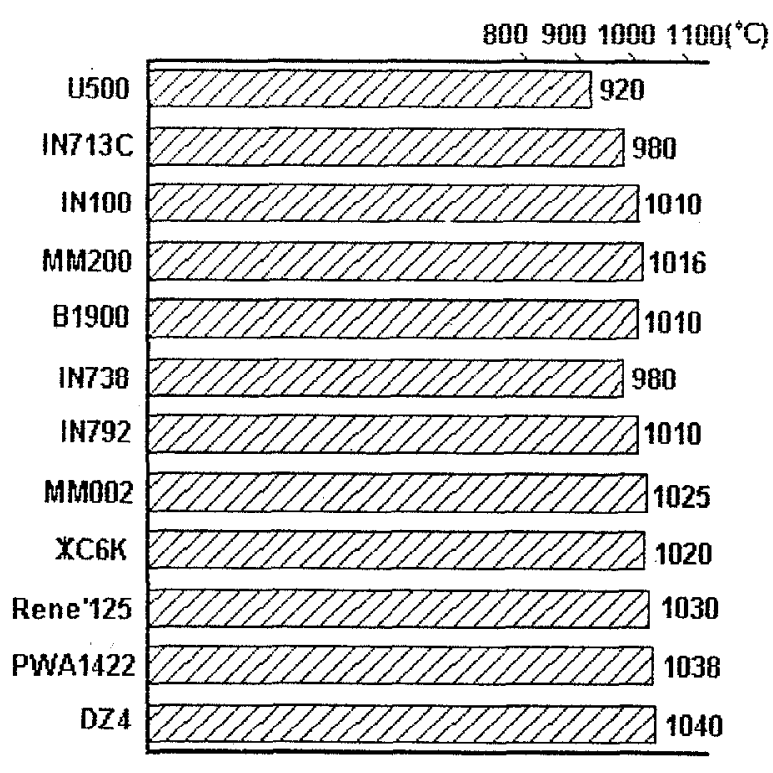

Figure 6. Temperature Capability of Alloy DZ4 and Some Typical Superalloys Widely Used in Turbine Engines (Normalized for 100 Hour Stress Rupture Life at $137 \mathrm{MPa}$ )
A complete mechanical property characterization of alloy DZ4 was conducted during alloy development. Alloy properties were determined directly from cast parts. Thin wall property tests are shown in Table VI [7], where transverse and longitudinal stressrupture properties at 760 and $950^{\circ} \mathrm{C}$ are listed for DZ4 and IN-100 using specimens cut from hollow DS first stage blades. Both DZ4 and IN-I00 have the same rupture ductility but DZ4 exhibits rupture life 10 times higher than that of IN-100. Table VI shows the comparison of thin wall rupture properties for DZ4 and IN-100 using sheet samples of $1.0 \mathrm{~mm}$ thickness cut from the airfoils of second stage turbine blades. Both the rupture life and ductility of alloy DZ4 are superior to that of IN-I00.

Table V Specific Stress-Rupture Strength (Rupture/Alloy Density) for DZ4 and Other Superalloys

\begin{tabular}{|l|l|l|l|l|l|l|l|l|}
\hline \multirow{2}{*}{$\begin{array}{l}{ }^{\circ} \mathrm{C} \\
\text { Alloy }\end{array}$} & \multicolumn{6}{|c|}{ Specific 100 Hr. Rupture Strength MPa.cm $/ \mathrm{g}$} \\
\cline { 2 - 9 } & 760 & 800 & 850 & 900 & 950 & 980 & 1000 & 1040 \\
\hline DZ4 & 98.7 & 82.9 & 63.7 & 43.2 & 29.9 & 25.2 & 22.1 & 17.3 \\
\hline DZ22 & 93.7 & & 61.7 & & & 24.0 & & 15.9 \\
\hline PWA 1422 & 88.2 & & & & & 23.3 & & 14.8 \\
\hline DZ3 & 95.5 & 77.4 & 60.4 & 42.3 & 29 & 25.3 & 21.5 & 16.8 \\
\hline K403 & & 64.1 & 49.5 & 36.2 & 26.5 & & 18.1 & \\
\hline IN100 & & 70.2 & 54 & 40.1 & 26.3 & & 18.8 & \\
\hline DZ5 & 92.3 & 77.2 & 62.7 & 41 & 30.1 & 25.3 & 21.7 & \\
\hline DZ17G & 91 & 75.8 & & 41.6 & 27.7 & 22.7 & 19.6 & \\
\hline DS B-1900 & 85 & 72.6 & 56 & 41.4 & 27.3 & 22.6 & 19.6 & \\
\hline DS IN-100 & 85.9 & & & & & 22.1 & & \\
\hline DS MM002 & 87.1 & 74.8 & 59.9 & 42.3 & 29.4 & & 21.3 & 16.4 \\
\hline
\end{tabular}

Table VI Transverse and Longitudinal Stress-Rupture Properties for Hollow DZ4 DS and IN-100 Equiaxed Blades

\begin{tabular}{|c|c|c|c|c|c|c|c|c|}
\hline \multirow{2}{*}{$\begin{array}{l}\text { Specimen } \\
\text { Machining } \\
\text { Location }\end{array}$} & \multirow{2}{*}{ Alloy } & \multirow{2}{*}{$\begin{array}{l}\text { Specimen } \\
\text { Orientation }\end{array}$} & \multirow{2}{*}{$\begin{array}{l}\text { Specimen } \\
\text { Size mm }\end{array}$} & \multicolumn{5}{|c|}{ Stress Rupture Test Data } \\
\hline & & & & $\begin{array}{c}\text { Temp } \\
\text { C }\end{array}$ & $\begin{array}{l}\text { Stress } \\
\mathrm{MPa}\end{array}$ & $\begin{array}{c}\text { Life } \\
\text { hrs }\end{array}$ & $\begin{array}{c}\text { Elong } \\
\%\end{array}$ & $\begin{array}{c}\mathrm{RA} \\
\%\end{array}$ \\
\hline$\sqrt{!}$ & DZ4 & $\begin{array}{l}\text { Transverse } \\
\text { DS }\end{array}$ & diam. $=3$ & $\begin{array}{l}760 \\
950 \\
\end{array}$ & $\begin{array}{l}647 \\
235 \\
\end{array}$ & $\begin{array}{r}39: 25 \\
41: 55 \\
252: 00 \\
\end{array}$ & $\begin{array}{l}3.33 \\
3.36\end{array}$ & $\begin{array}{r}9.59 \\
10.18\end{array}$ \\
\hline 望要 & IN100 & Equiaxed & diam. $=3$ & 760 & 647 & $\begin{array}{l}4: 25 \\
4: 00\end{array}$ & $\begin{array}{l}6.67 \\
2.00\end{array}$ & $\begin{array}{r}17.90 \\
5.10\end{array}$ \\
\hline 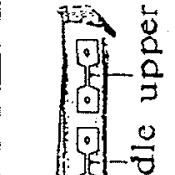 & DZ4 & $\begin{array}{l}\text { Axial DS } \\
\text { Top } \\
\text { Middle } \\
\text { Lower }\end{array}$ & thick. $=1$ & 760 & 647 & $\begin{array}{l}595: 40 \\
781: 50 \\
615: 45\end{array}$ & $\begin{array}{l}17.80 \\
17.80 \\
20.00\end{array}$ & \\
\hline $\begin{array}{r}a \\
10 \\
\square \\
\square\end{array}$ & IN 100 & $\begin{array}{l}\text { Equiaxed } \\
\text { Top } \\
\text { Middle } \\
\text { Lower }\end{array}$ & thick. $=1$ & 760 & 647 & $\begin{array}{l}99: 35 \\
48: 00 \\
28: 30\end{array}$ & $\begin{array}{l}9.99 \\
7.77 \\
7.77\end{array}$ & \\
\hline
\end{tabular}


Vibratory Fatigue Performance of Blades

Figure 7 presents a comparison of S-N curves [7] obtained in vibration fatigue tests using blades made from DZ4 alloy and IN100 , which DZ4 has replaced in a jet engine. At room temperature the fatigue limits for $1 \times 10^{7}$ cycles for DZ4 and IN-100 are 225$254 \mathrm{MPa}$ and 147-176 MPa, respectively.

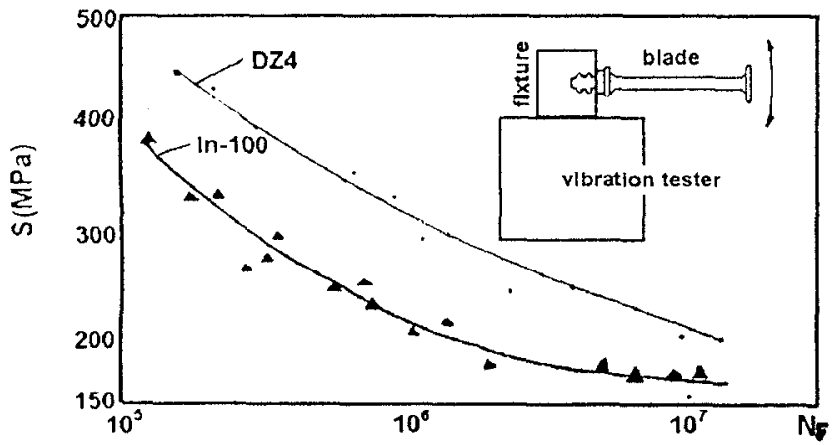

Figure 7. Vibration Fatigue Curves for Blades Made From DZ4 and IN-100 Alloys

Thermal Mechanical Fatigue

Thermal mechanical fatigue test results are shown in Table 8 and Figure 8 [7]. As presented in Figure 8, service life can be estimated from the stresses imposed on the component. For example, when the service stress on a DZ4 alloy turbine blade is $196 \mathrm{MPa}$, its fatigue life can be estimated at 10,000 cycles or more by using the thermal mechanical fatigue curve in the figure.

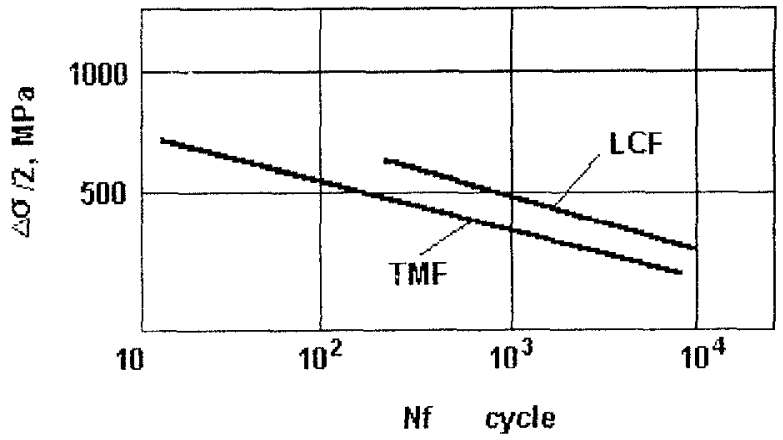

Figure 8. Thernial Mechanical Fatigue and Low Cycle Fatigue Curves for $\mathrm{DZ} 4$ at $980^{\circ} \mathrm{C}$

Specification Properties

In order to compare overall properties versus an existing production DS alloy, PWA 1422 was selected for benchmarking. This alloy is employed in first stage high pressure turbine blades in F100 jet engines.[8] DZ4 was tested at specification conditions called out in the PWA $1422 \mathrm{~K}$ specification and presented in Table IX. Also crecp curves at $980^{\circ} \mathrm{C} / 193 \mathrm{MPa}$ for both PW 1422 and DZ4 are plotted and compared in Figure 9. It is evident that the two alloys have basically the same level of mechanical properties.

Table IX Comparison of Mechanical Properties for the Alloy DZ4 and PWA 1422

\begin{tabular}{|c|c|c|c|}
\hline $\begin{array}{l}\text { PWA } 1422 \\
\text { Mechanical } \\
\text { Property Test } \\
\text { Conditions }\end{array}$ & $\begin{array}{l}\text { PWA } 1422 \\
\text { Specification } \\
\text { Requirements }\end{array}$ & $\begin{array}{l}\text { DZ4 Alloy } \\
\text { Test Results }\end{array}$ & $\begin{array}{l}\text { PWA } 1422 \\
\text { Referenced } \\
\text { Data }\end{array}$ \\
\hline $\begin{array}{l}\text { Tensile Properties } \\
\text { at Room Temp }\end{array}$ & $\begin{array}{l}\text { UTS }>1030 \mathrm{MPa} \\
\text { Y }>980 \mathrm{MPa} \\
\text { Elong }(4 \mathrm{~d})>13 \%\end{array}$ & $\begin{array}{c}1040-1197 \mathrm{MPa} \\
932-961 \mathrm{MPa} \\
5-7 \%\end{array}$ & $\begin{array}{c}1106 \mathrm{MPa} \\
942 \mathrm{MPa} \\
6.1 \%\end{array}$ \\
\hline $\begin{array}{l}\text { Stress-Rupture at } \\
760 \mathrm{C} / 690 \mathrm{MPa}\end{array}$ & $\begin{array}{l}\text { Life }>48 \mathrm{hrs} \\
\text { Creep at } 48 \mathrm{hrs}<4 \%\end{array}$ & $\begin{array}{c}800-1000 \text { hrs } \\
<1.9 \%\end{array}$ & $700 \mathrm{hrs}$ \\
\hline $\begin{array}{l}\text { Stress-Rupture at } \\
980 \mathrm{C} / 220 \mathrm{MPa}\end{array}$ & $\begin{array}{l}\text { Life }>32 \mathrm{hrs} \\
\text { Creep at } 32 \mathrm{hrs}<2 \%, \\
\text { Creep at Rupt. }>10 \%\end{array}$ & $\begin{array}{c}56-70 \mathrm{hrs} \\
1.5 \% \\
16-20 \%\end{array}$ & $129 \mathrm{hrs}$ \\
\hline $\begin{array}{l}\text { Stress-Rupture at } \\
1093 \mathrm{C} / 82.8 \mathrm{MPa} \\
\text { (for vanes or buckets) }\end{array}$ & $\begin{array}{l}\text { Life }>40 \text { hrs } \\
\text { Crecp at Rupt. }>10 \%\end{array}$ & $\begin{array}{c}50-61 \mathrm{hrs} \\
22-32 \%\end{array}$ & \\
\hline $\begin{array}{l}\text { Stress-Rupture at } \\
1270 \mathrm{C} / 68 \mathrm{MPa} \\
\text { (transverse-not } \\
\text { reguired) }\end{array}$ & & $\begin{array}{c}64.7 \mathrm{MPa} \\
196 \mathrm{hrs}\end{array}$ & $170 \mathrm{hrs}$ \\
\hline
\end{tabular}




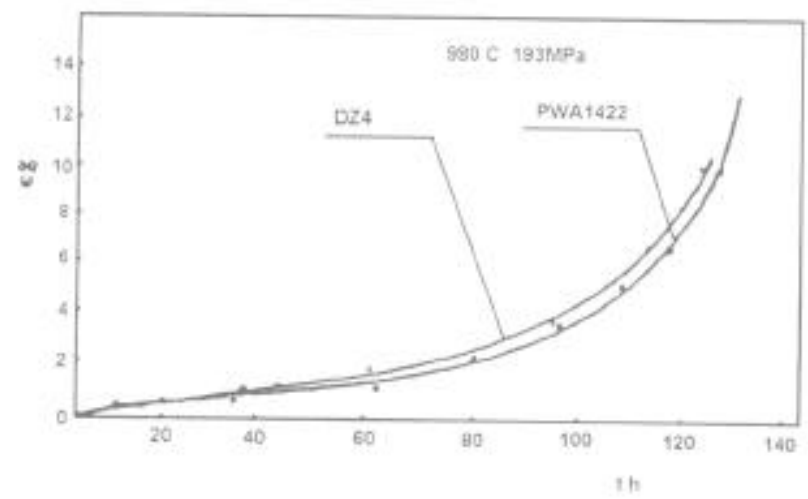

Figure 9. Creep Curves at $980^{\circ} \mathrm{C} / 193 \mathrm{MPa}$ for Alloy DZ4 and PWA. 1422

\section{Engincering Applicutions}

In the present paper the engineering applications of the Hf-free DZ4 alloy, now in full scale production in China, were reported.

Annual consumption of $\mathrm{Hf}$-free DZ4 alloy has reached 40 tons per year since 1992, and is growing rapidly with increased DZ4 usage for blades and guide vanes in modified and newly designed aeroengines and land based turbines. It now has entered service in marine, locomotive and petroleum industry applications.

The DS biades and vanes made from Hf-free DZ4 alloy include both hollow and solid castings and their sizes vary from tens of mm up to $200 \mathrm{~mm}$. In Figure 9, two buckets are preserited, one of them typically is a fabricated component made by yacuum brazing of DS airfoils and the other one (on the right) is integrally DS cast from Hf-free DZA alloy. In making complex components like this. the requirements for castability are even more stringent. Parts cast from alloy DZA have never experienced casting cracking. Accumulated service life for turbine blades made from DZ4 alloy has exceeded 8000 hours on more than 100 jet turbine engines flying over 3 years. Routine examinations indicate no blade distress has occurred to date. Measurements of blade clongation has revealed that the airfoils are just about to enter the steady state creep stage. As shown in Figure 11, the microstructure of a blade which has accumulated over 8000 flight hours, exhibits no change in $\gamma^{\prime}$ morphology and size. This in turn proves that the blade still has considerable life remaining. Over 30,000 blades, $188 \mathrm{~mm}$ in length, have been produced. Production casting yields with DZ4 are higher than that of equiaxed blades owing to the absence of metallurgical defects such as porosity and inclusions. In addition. the reproducibility is also higher. Replacement of an older alloy in a hollow first stage turbine blade by DZ4 (see Figure 12), has resulted in service life being extended by 10 times that of the original. Hollow blades and vanes with sophisticated cooling passages have been successfully cmployed in advanced acroengines. It is worth noting, that no blades have been rejected for hot tearing among tens of thousands of blades cast with the production process. No hot tearing appears even when the ceramic core deforms during the casting of a $160 \mathrm{~mm}$ long blade with a thin and narrow airfoil, leading to a very thin wall $(0.1 \mathrm{~mm}$ wall thickness),

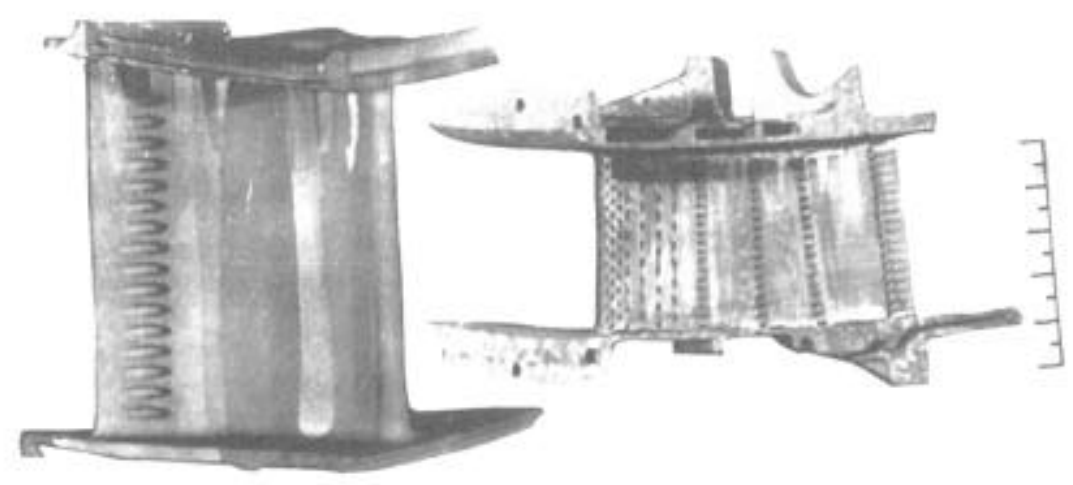

Figure 10. Blade and Guide Vanes Made from Hf-Free. Alloy DZ4 

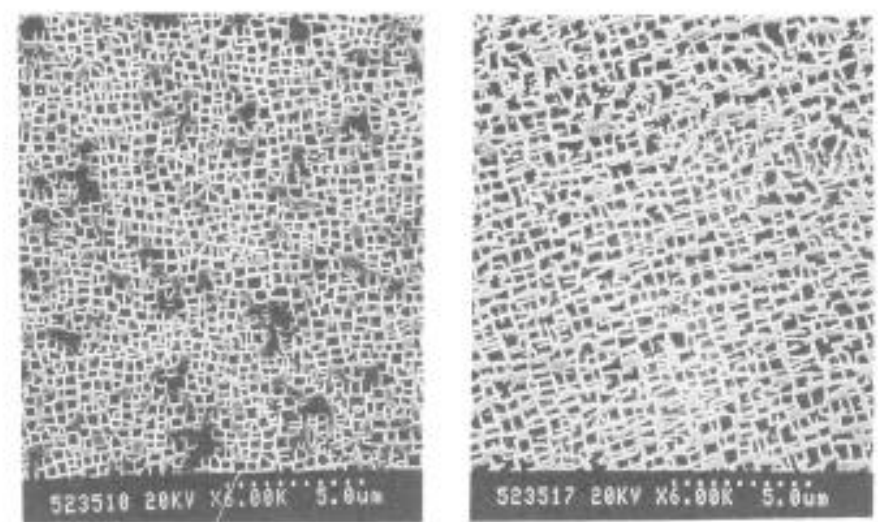

Figure 11. Microstructure of DZ4 Blade After 8000 Hours of Service As Heat Treated (Left) and After 8000 Hours in Service (Right)

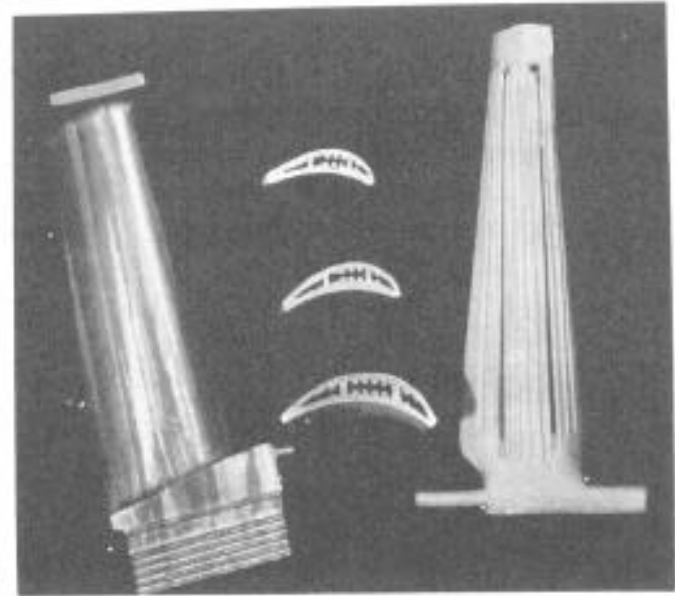

Figure 12, A Hollow Blade Made from DZ4

\section{Conclusions}

1. The DZ4 Hi-free directionally solidified superalloy is characterized by low cost, low density and high specific strength.

2. The climination of $\gamma / \gamma^{\prime}$ eutectic phase in the DZ4 alloy greatly increases the incipient melting temperature and reduces the temperature range between the liquidus and solidus making it possible to increase high temperature performance and at the same time improve castability.

3. The Hi-free DZ4 alloy possesses mechanical properties essentially equivalent to that of the advanced Hf-containing DS superalloy PWA 1422

4. The many applications of the Hf-free DZA superalloy indicate that it has successfully met its program goals of high castability and improved high temperature properties.

\section{References}

[1] D.N.Duhl and C.P.Sullivan, "Some Effects of Hafnium Additions on the Mechanical Properties of a Columnar Grained Nickel Base Superalloy", J. Metals, 23 (7) (1971), 38-40

[2] Zheng Yunrong, "The Effects of Hafnium Additions on the Solidification of Cast Superalloys", Journal of Metals of China. Vol. 22, No. 2. April 1986, 119-124

[3] Wilfried Kurz, "Microsegregation in Direetionally Solidified Superalloys", Proc of the 13th International Congress on Combustion Engines (CIMACT) Vienna 7th-1] th May 1979

[4] Zheng Yunrong and Chen Hong, "Solidification Characteristics of Two Kinds of Directionally Solidified Superalloys, DZ3 and DZ4", Acronautical Materials, 1 (1985), 10-16

[5] Sun Chuanqi et,al. "A Study of the Castability of DZ4 DS Superalloy", Aeronautical Materials, 3 (1984), 1-6 [6] C.S. Wakusick et al, US Patent 4169742, 1979 [7] Sun Chanqi et al, "Report on Superalloy DZ4", Beijing Institute of Aeronautical Materials, Unpublished Internal Report [8] Pratt \& Whitney, TM Specification PWA 1422F Nov, 1972 